\title{
Several Issues in the Development of Ti-Nb-Based Shape Memory Alloys
}

\author{
Hee Young $\mathrm{Kim}^{1} \cdot$ Shuichi Miyazaki ${ }^{1,2}$
}

Published online: 28 November 2016

(c) ASM International 2016

\begin{abstract}
Ni-free Ti-based shape memory alloys, particularly $\mathrm{Ti}-\mathrm{Nb}$-based alloys, have attracted increasing attraction since the early 2000s due to their wide application potentials in biomedical fields. Recently, there has been significant progress in understanding the martensitic transformation behavior of Ti-Nb-based alloys and many novel superelastic alloys have been developed. The superelastic properties of $\mathrm{Ti}-\mathrm{Nb}$-based alloys have been remarkably improved through the optimization of alloying elements and microstructure control. In this paper, in order to explore and establish the alloy design strategy, several important issues in the development of Ti-Nb-based shape memory alloys are reviewed. Particularly, the effects of alloying elements on the martensitic transformation temperature and the transformation strain are analyzed. The effects of omega phase and texture on the superelastic properties are also discussed.
\end{abstract}

Keywords Martensite - Mechanical behavior - Shape memory alloys - Superelasticity - Transformation strain . Beta Ti alloy $\cdot$ Biomaterial

Hee Young Kim

heeykim@ims.tsukuba.ac.jp

$\triangle$ Shuichi Miyazaki

miyazaki@ims.tsukuba.ac.jp

1 Division of Materials Science, University of Tsukuba, Tsukuba, Ibaraki 305-8573, Japan

2 Foundation for Advancement of International Science, Tsukuba, Ibaraki 305-0821, Japan

\section{Introduction}

Over the past decade, there has been significant progress not only in understanding the martensitic transformation behavior of Ti-based alloys but also in developing novel biocompatible shape memory alloys [1-3]. In binary $\mathrm{Ti}-\mathrm{Nb}$ alloys, superelasticity has been reported to occur when the $\mathrm{Ni}$ content is in the range of 26-27 at.\% [4, 5]. However, the superelastic properties of $\mathrm{Ti}-(26,27) \mathrm{Nb}$ alloys are not good enough, particularly in terms of recovery strain, when compared with practical Ti-Ni superelastic alloys [5]. The superelasticity of $\mathrm{Ti}-\mathrm{Nb}$ alloys is associated with the stress-induced martensitic transformation from the parent $(\beta)$ phase to the martensite $\left(\alpha^{\prime \prime}\right)$ phase and its revision. It has been concluded that the small recovery strain is mainly due to the intrinsic small transformation strain of the $\beta-\alpha^{\prime \prime}$ transformation. [3, 5]. Another drawback of $\mathrm{Ti}-\mathrm{Nb}$ alloys to be mentioned is low critical stress for slip. These drawbacks have prompted researchers to develop new alloys. Many kinds of Ti-Nb-based alloys have been developed to date, e.g., Ti-Nb-Sn [6-9], Ti-Nb-Al [10-12], Ti-Nb-O [13, 14], Ti-Nb-N [14, 15], Ti-Nb-Mo [16], Ti-Nb-Pt [17], Ti-Nb-Pd [18], Ti-Nb-Ta [19-23], Ti-Nb-Zr [24-31], Ti-Nb-Ta-Zr [32-34], Ti-Nb-Mo-Sn [35-38], Ti-Nb-Zr-Sn [39-43], Ti-Nb-Zr-Al [44], and Ti-Nb-Zr-Mo-Sn [45]. Through these efforts, superelastic properties have been significantly improved over the last 10 years. However, the influence of alloying elements on the martensitic transformation characteristics has not been fully elucidated. There have been only limited quantitative studies to assess the effect of alloying elements on the crystal structure of martensite phase, transformation temperature, and transformation strain. In this paper, several important issues in the development of Ti-Nb-based shape memory alloys are reviewed in order to establish an alloy 
design strategy for biomedical superelastic alloys. All the compositions mentioned in the paper are given in at.\%.

\section{Transformation Strain and Transformation Temperature}

One of the critical issues that need to be addressed is the transformation strain because the shape recovery strain is intrinsically dependent on the transformation strain. The transformation strain induced by the martensitic transformation is determined by the lattice strain (Bain strain) and lattice correspondence. Figure 1 shows the lattice correspondence between $\beta$ parent and $\alpha^{\prime \prime}$ martensite phases. The lattice correspondence is expressed as follows:

$[100]_{\alpha^{\prime \prime}}-[100]_{\beta},[010]_{\alpha^{\prime \prime}}-[011]_{\beta},[001]_{\alpha^{\prime \prime}}-[0 \overline{1} 1]_{\beta}$.

The lattice strains in three principal axes of the orthorhombic structure are calculated as follows:

$\eta_{1}=\frac{a^{\prime}-a_{0}}{a_{0}}, \eta_{2}=\frac{b^{\prime}-\sqrt{2} a_{0}}{\sqrt{2} a_{0}}, \eta_{3}=\frac{c^{\prime}-\sqrt{2} a_{0}}{\sqrt{2} a_{0}}$,

where $a^{\prime}, b^{\prime}$, and $c^{\prime}$ denote the lattice constants of the $\alpha^{\prime \prime}$ martensite phase and $a_{0}$ is the lattice constant of the $\beta$ parent phase. Recently, the effects of composition on the lattice constants of the $\beta$ and $\alpha^{\prime \prime}$ phases have been investigated in Ti-Nb binary alloys $[5,46,47]$ and some ternary alloys such as $\mathrm{Ti}-\mathrm{Nb}-\mathrm{Zr}$ [48-50], Ti-Nb-Ta [48-51], and Ti-Nb-Mo [16] alloys.
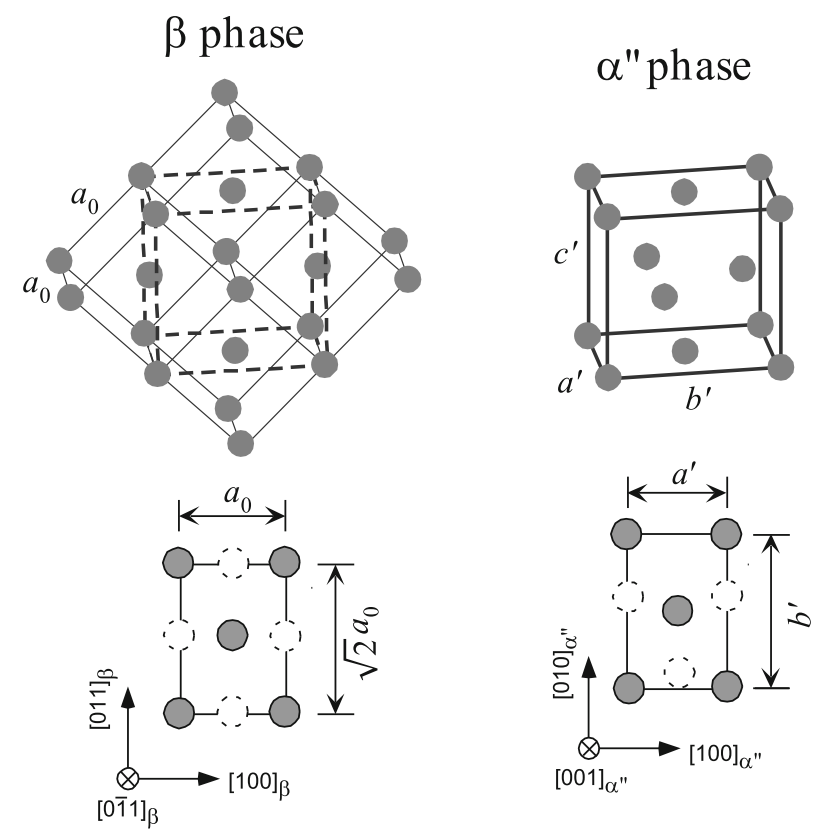

Fig. 1 Crystal structures of $\beta$ and $\alpha^{\prime \prime}$ phases and their lattice correspondences
The composition dependences of $\eta_{1}, \eta_{2}$, and $\eta_{3}$ are shown as a function of $\mathrm{Nb}$ content in Fig. 2a for $\mathrm{Ti}-\mathrm{Nb}-\mathrm{Zr}$ alloys and in Fig. 2b for Ti-Nb-Ta alloys [49], respectively. It can be seen from Fig. 2 a that $\eta_{1}$ and $\eta_{2}$ are of similar magnitudes but opposite signs, i.e., $\eta_{1}$ is negative, while $\eta_{2}$ is positive, implying that the martensitic transformation contracts the lattice in the $[100]_{\beta}$ direction while expanding the lattice in the $[011]_{\beta}$ direction. Figure $2 \mathrm{a}$ also demonstrates that the absolute magnitudes of $\eta_{1}$ and $\eta_{2}$ decrease with increasing $\mathrm{Nb}$ content, indicating that the lattice strain decreases as the $\mathrm{Nb}$ content increases. It is also noted that the addition of $\mathrm{Zr}$ decreases the
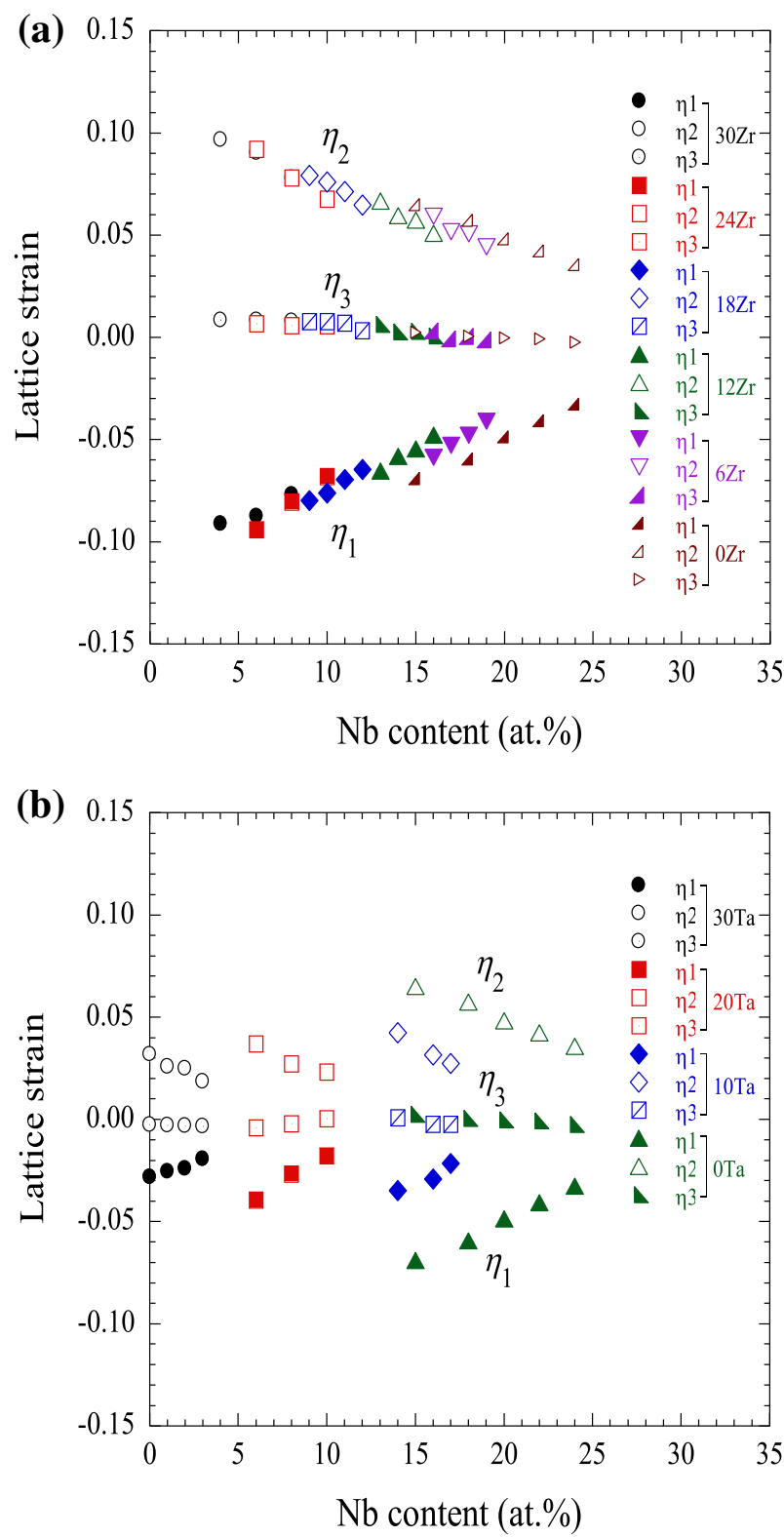

Fig. 2 Composition dependence of the principal lattice deformation strains of a $\mathrm{Ti}-\mathrm{Nb}-\mathrm{Zr}$ and $\mathbf{b} \mathrm{Ti}-\mathrm{Nb}-\mathrm{Ta}$ alloys 
transformation strains but the effect is much less pronounced than that of $\mathrm{Nb}$ owing to the fact that the lattice constants of the $\alpha^{\prime \prime}$ phase of the Ti-Nb-Zr alloys are less sensitive to $\mathrm{Zr}$ content. On the other hand, it can be seen from Fig. $2 b$ that the increase in Ta content at a fixed $\mathrm{Nb}$ content remarkably reduces the absolute magnitudes of $\eta_{1}$ and $\eta_{2}$.

The transformation strain is a function strongly affected by crystal orientation. Figure 3 shows [001] - [011] [111] standard stereographic triangles of the $\beta$ phase [49], representing orientation dependence of the transformation strain along the tensile direction expressed by contour lines. The results for $\mathrm{Ti}-10 \mathrm{Nb}, \mathrm{Ti}-10 \mathrm{Nb}-20 \mathrm{Ta}$, and $\mathrm{Ti}-$ $10 \mathrm{Nb}-20 \mathrm{Zr}$ alloys are compared to assess the effect of $\mathrm{Zr}$ and Ta on the transformation strain. The largest strain is obtained along the [011] direction, while the smallest strain is obtained along the [111] direction. The transformation strain along the [011] direction of the $\mathrm{Ti}-10 \mathrm{Nb}$ alloy is calculated to be $8.3 \%$, indicating that $\mathrm{Ti}-\mathrm{Nb}$ alloys have the potential to exhibit a large recovery strain. The addition of Ta significantly reduces the transformation strain: the transformation strain of the Ti-10Nb-20Ta alloy decreases to $2.5 \%$ along the [011] direction. On the other hand, the addition of $\mathrm{Zr}$ causes a little effect on the transformation strain: the transformation strain along the [011] direction decreases to $7.5 \%$ by the addition of 20 at. $\% \mathrm{Zr}$.

Figure 4 shows the composition dependences of the transformation strain along the [011] direction, which is the crystallographic orientation representing the largest transformation strain, of the $\mathrm{Ti}-\mathrm{Nb}-\mathrm{Zr}$ and $\mathrm{Ti}-\mathrm{Nb}-\mathrm{Ta}$ ternary alloys [49]. Figure 4 also shows the compositions exhibiting shape memory effect and superelasticity, marked by open circles and solid circles, respectively. It can be seen that the superelasticity occurs at room temperature in a wide composition range in both $\mathrm{Ti}-\mathrm{Nb}-\mathrm{Zr}$ and $\mathrm{Ti}-\mathrm{Nb}-\mathrm{Ta}$ alloys. It is noted that the addition of $\mathrm{Zr}$ as a substitute of $\mathrm{Nb}$ with keeping superelasticity increases the transformation strain. The transformation strain in the Ti-
$27 \mathrm{Nb}$ alloy is only $2.6 \%$ but it increases about two times by the addition of 18 at.\% Zr. Furthermore, a large transformation strain (more than 7\%) is expected in the alloys with high $\mathrm{Zr}$ content (more than 30 at.\%). On the other hand, the increase of $\mathrm{Ta}$ content in $\mathrm{Ti}-\mathrm{Nb}-\mathrm{Ta}$ alloys with keeping superelasticity decreases the transformation strain. The transformation strain decreases to $1.7 \%$ in a $\mathrm{Ti}-19 \mathrm{Nb}$ $10 \mathrm{Ta}$ alloy and $1.2 \%$ in a $\mathrm{Ti}-13 \mathrm{Nb}-20 \mathrm{Ta}$ alloy. This opposite effect of $\mathrm{Zr}$ and $\mathrm{Ta}$ on the transformation strain at the composition exhibiting superelasticity is due to the different effects of alloying elements on transformation temperature and lattice distortion strain.

The effects of alloying elements on the $\beta-\alpha^{\prime \prime}$ martensitic transformation temperature $\left(M_{\mathrm{s}}\right)$ and transformation strain along the [011] direction in $\mathrm{Ti}-\mathrm{Nb}$ alloys are summarized in Table 1 [3]. Alloy compositions showing superelasticity at RT are also shown in Table 1. For the Ti-Nb binary alloys, $M_{\mathrm{s}}$ decreases with the increasing $\mathrm{Nb}$ content with a slope of about $-40 \mathrm{~K} / \mathrm{at} . \%$ and the superelasticity is observed at the composition of Ti- $(26,27) \mathrm{Nb}$. As the $\mathrm{Nb}$ content increases, the transformation strain decreases with a slope of $-0.34 \% / a t . \%$ until it reaches $2.6 \%$ at the superelastic composition of Ti-27Nb. All alloying elements reported in literature reduce $M_{\mathrm{s}}$ and transformation strain of Ti-Nb alloys. The addition of Ta decreases $M_{\mathrm{s}}$ and transformation strain of a Ti-22Nb alloy by $30 \mathrm{~K} /$ at. $\%$ and by $0.28 \% / a t . \%$, respectively, resulting in a smaller transformation strain at the superelastic composition (Fig. 4). The addition of $\mathrm{Zr}$ in the Ti-22Nb alloy also decreases $M_{\mathrm{s}}$ and transformation strain by $35 \mathrm{~K} / \mathrm{at} . \%$ and $0.13 \% / a t . \%$, respectively. It is noted that the addition of $\mathrm{Zr}$ has a weaker effect on the transformation strain, while it decreases the transformation temperature with a similar effect as $\mathrm{Nb}$. As a result, the increase in the $\mathrm{Zr}$ content as a substitute of $\mathrm{Nb}$ while maintaining the same transformation temperature increases the transformation strain in agreement with the experimental observations (Fig. 4) [49]. Mo has strong decreasing effects on both the transformation temperature and transformation strain, but the impact on the

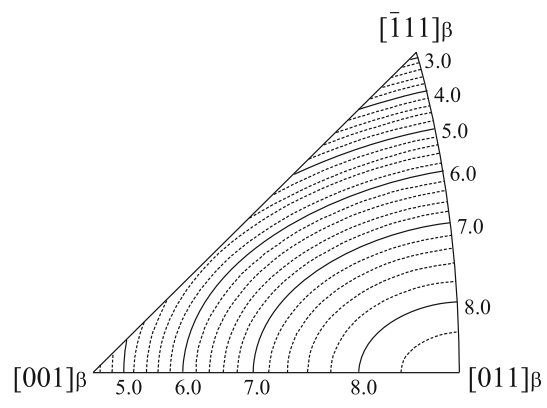

$\mathrm{Ti}-10 \mathrm{Nb}$

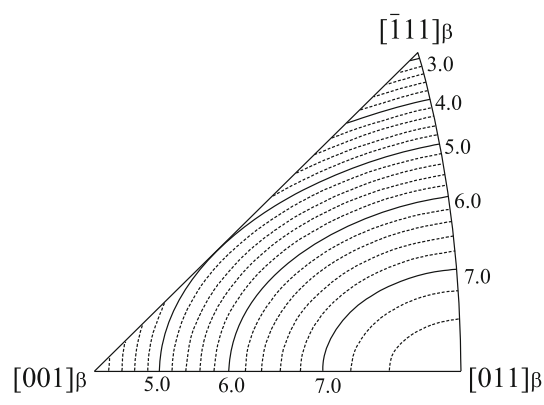

Ti-10Nb-20Zr

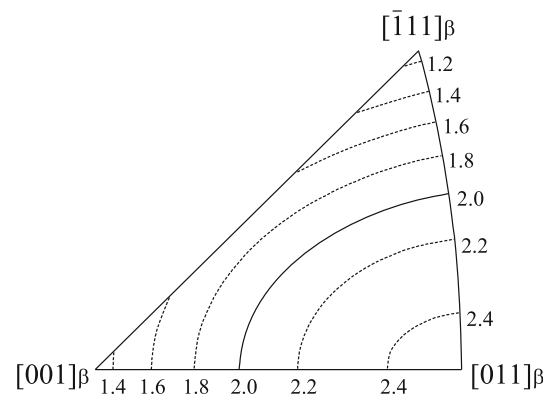

$\mathrm{Ti}-10 \mathrm{Nb}-20 \mathrm{Ta}$

Fig. 3 Orientation dependence of the calculated transformation strain of Ti-10Nb, Ti-10Nb-20Ta, and Ti-10Nb-20Zr alloys 

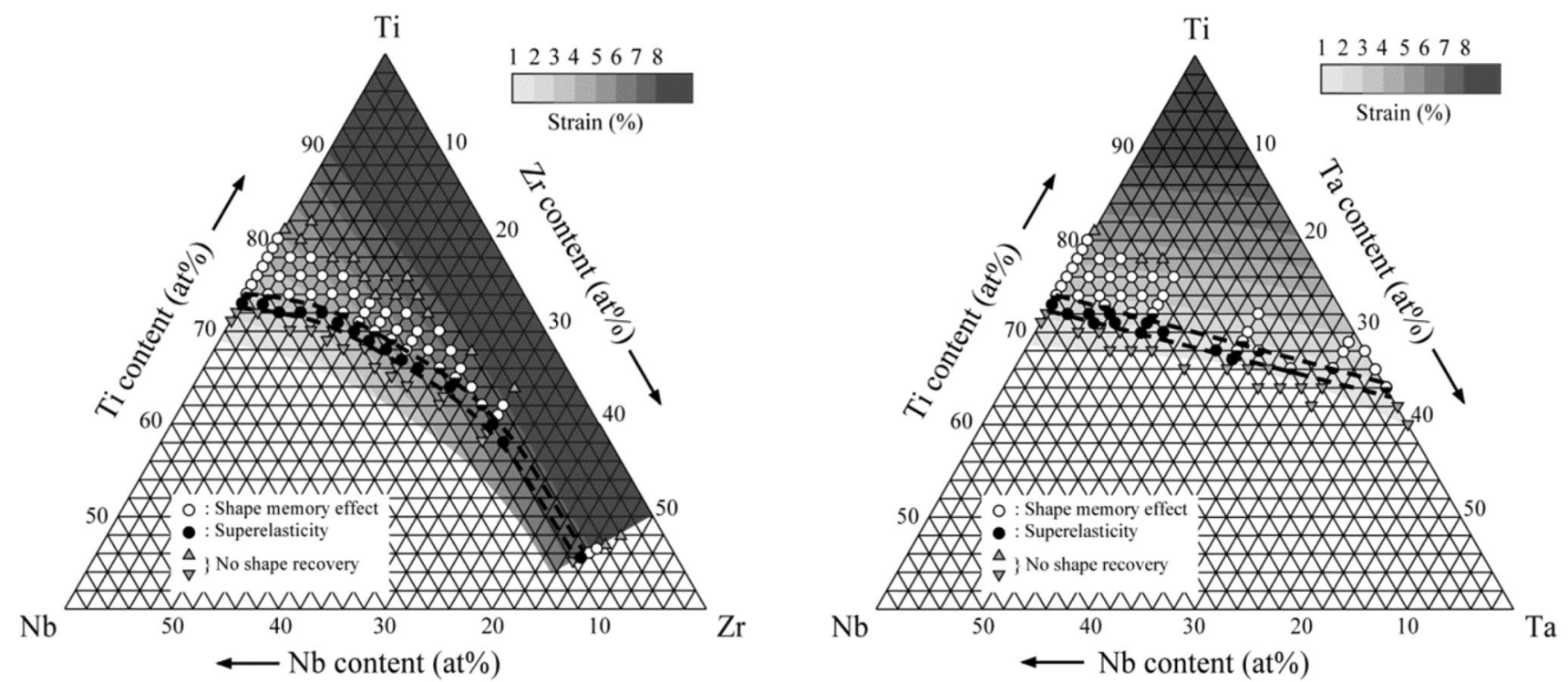

Fig. 4 Composition dependence of transformation strain along the [011] direction and shape memory properties in $\mathrm{Ti}-\mathrm{Nb}-\mathrm{Zr}$ and $\mathrm{Ti}-\mathrm{Nb}-\mathrm{Ta}$ alloys

Table 1 Effects of alloying elements on $M_{\mathrm{s}}$ and transformation strain along the [011] direction in Ti-Nb binary and Ti-Nb-X ternary alloys

\begin{tabular}{|c|c|c|c|c|}
\hline $\begin{array}{l}\text { Alloying } \\
\text { element }\end{array}$ & $\begin{array}{l}\text { Effect in changing } M_{\mathrm{s}} \\
\text { temperature }(\mathrm{K} / \text { at. } \%)\end{array}$ & $\begin{array}{l}\text { Effect in changing transformation } \\
\text { strain }(\% / a t . \%)\end{array}$ & $\begin{array}{l}\text { Alloy composition showing } \\
\text { superelasticity at RT }\end{array}$ & \\
\hline $\mathrm{Nb}$ & -40 & -0.34 & $\mathrm{Ti}-(26,27) \mathrm{Nb}$ & {$[5]$} \\
\hline $\mathrm{Ta}$ & -30 & -0.28 & $\mathrm{Ti}-22 \mathrm{Nb}-(6,7) \mathrm{Ta}$ & {$[19,49]$} \\
\hline Mo & -120 & -0.89 & $\begin{array}{l}\mathrm{Ti}-24 \mathrm{Nb}-1 \mathrm{Mo}, \mathrm{Ti}-21 \mathrm{Nb}-2 \mathrm{Mo}, \mathrm{Ti}- \\
18 \mathrm{Nb}-3 \mathrm{Mo}\end{array}$ & {$[16]$} \\
\hline $\mathrm{Pt}$ & -160 & -0.95 & $\mathrm{Ti}-19 \mathrm{Nb}-2 \mathrm{Pt}$ & [17] \\
\hline $\mathrm{Cu}$ & -100 & & $\mathrm{Ti}-18 \mathrm{Nb}-4 \mathrm{Cu}$ & {$[53]$} \\
\hline $\mathrm{Zr}$ & -35 & -0.13 & $\mathrm{Ti}-22 \mathrm{Nb}-6 \mathrm{Zr}, \mathrm{Ti}-15 \mathrm{Nb}-18 \mathrm{Zr}$ & {$[26,42,49]$} \\
\hline $\mathrm{Sn}$ & -150 & & $\mathrm{Ti}-16 \mathrm{Nb}-4.9 \mathrm{Sn}$ & {$[6]$} \\
\hline $\mathrm{Al}$ & -40 & -0.27 & $\mathrm{Ti}-24 \mathrm{Nb}-3 \mathrm{Al}$ & {$[10,52]$} \\
\hline $\mathrm{O}$ & -160 to 200 & & $\mathrm{Ti}-(22,23) \mathrm{Nb}-1 \mathrm{O}$ & {$[13,56]$} \\
\hline $\mathrm{N}$ & -200 & & $\mathrm{Ti}-(22-24) \mathrm{Nb}-1 \mathrm{~N}$ & {$[15]$} \\
\hline B & -350 & & $\mathrm{Ti}-26 \mathrm{Nb}-1 \mathrm{~B}$ & {$[57]$} \\
\hline
\end{tabular}

transformation temperature is much stronger. Therefore, the addition of Mo as a substitute of $\mathrm{Nb}$, while keeping the same transformation temperature, also increases the transformation temperature. The effect of Mo on the transformation strain has also been confirmed by the experiments [16]. Figure 5 shows the $\mathrm{Nb}$ content dependence of the transformation strain along the [011] direction for $\mathrm{Ti}-\mathrm{Nb}$ and $\mathrm{Ti}-\mathrm{Nb}-1 \mathrm{Mo}$ alloys [16]. When comparing the transformation strains of $\mathrm{Ti}-22 \mathrm{Nb}$ and $\mathrm{Ti}-19 \mathrm{Nb}-1 \mathrm{Mo}$ alloys, which exhibit a similar transformation temperature, it is clear that the substitution of 1 at. $\% \mathrm{Mo}$ for 3 at. $\% \mathrm{Nb}$ increases the transformation strain. Thus, the addition of Mo can increase the transformation strain at the superelastic compositions. The additions of $\mathrm{Pt}$ and $\mathrm{Al}$ show similar effects in increasing the transformation strain at superelastic compositions [10, 17, 52]. The addition of Sn remarkably reduces the transformation temperature: the increase in 1 at. $\% \mathrm{Sn}$ reduces the transformation temperature by $150 \mathrm{~K}$ [6]; however, quantitative information on the transformation strain has not been reported yet. It has also been reported that the $3 \mathrm{~d}$ transition metal elements such as $\mathrm{Cr}, \mathrm{Fe}, \mathrm{Co}, \mathrm{Ni}$, and $\mathrm{Cu}$, which are strong $\beta$ stabilizers, decrease the transformation temperature of $\mathrm{Ti}-\mathrm{Nb}$ base alloys [53, 54]. The addition of $\mathrm{Ga}$ and $\mathrm{Ge}$ also decreases the transformation temperature of Ti-Nb-based alloys [55]. However, there have only been limited efforts to examine the transformation temperature and transformation strain quantitatively. 


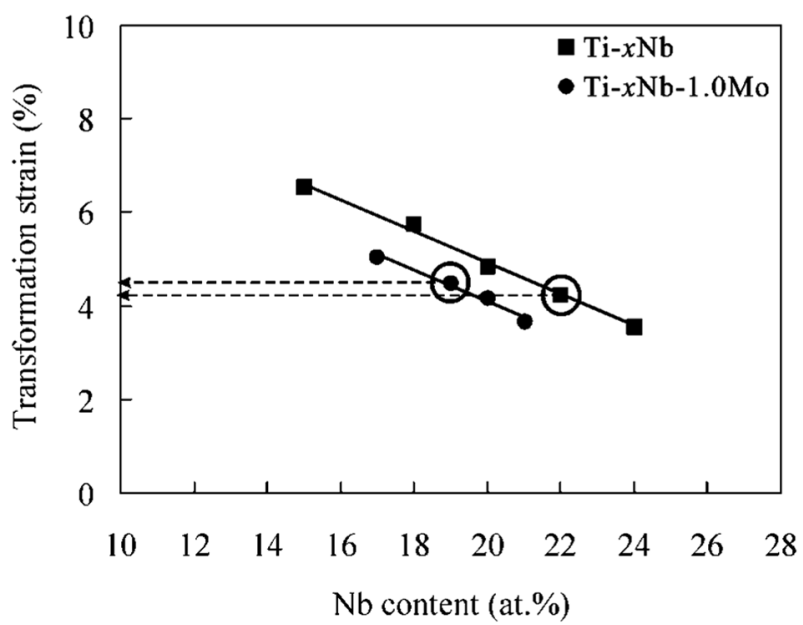

Fig. $5 \mathrm{Nb}$ content dependence of the transformation strain along the [011] direction for $\mathrm{Ti}-\mathrm{Nb}$ and $\mathrm{Ti}-\mathrm{Nb}-1 \mathrm{Mo}$ alloys

\section{Interstitial Alloying Elements}

The interstitial alloying elements such as $\mathrm{O}$ and $\mathrm{N}$ have attracted attention not only due to strengthening effect but also due to their significant effect on the martensitic transformation and deformation behavior of $\mathrm{Ti}-\mathrm{Nb}$ alloys. Figure 6 shows the effect of oxygen addition on the shape memory properties of $\mathrm{Ti}-\mathrm{Nb}$ alloys. The $\mathrm{Ti}-\mathrm{Nb}$ binary alloys exhibit superelastic recovery at room temperature when the $\mathrm{Nb}$ content is $26-27$ at.\%. The $\mathrm{Ti}-(20-25) \mathrm{Nb}$ alloys exhibit shape memory effect: the residual strain is recovered upon heating up to $500 \mathrm{~K}$. For the $\mathrm{Ti}-\mathrm{Nb}-1 \mathrm{O}$ alloys, superelastic recovery is observed in the alloys with a lower $\mathrm{Nb}$ content, i.e., 22-24 at.\%, indicating that $\mathrm{O}$ suppresses the martensitic transformation. It is suggested from the results of Fig. 6 that the effect of the addition of 1 at. $\% \mathrm{O}$ on the martensitic transformation temperature is equivalent to that of $4-5$ at. $\% \mathrm{Nb}$, implying that the martensitic transformation temperature decreases by 160-200 per 1 at.\% O. The increase in the O content changes the mechanism of superelasticity. Figure 7 shows the effect of the $\mathrm{O}$ content on the stress-strain curves during a loading-unloading cycle with a maximum strain of $1.5 \%$ for the $\mathrm{Ti}-23 \mathrm{Nb}-2 \mathrm{Zr}-0.7 \mathrm{Ta}-x \mathrm{O}$ alloys [58]. The $0.3 \mathrm{O}$ alloy shows superelasticity with a distinct change in slope on the stress-strain curve and stress hysteresis. As the $\mathrm{O}$ content increases, the apparent yield stress increases and the change of slope of the stress-strain curve after the pure elastic region becomes unobvious. Furthermore, the stress hysteresis becomes narrower with the increasing $\mathrm{O}$ content and the 1.50 and 1.80 alloys exhibit nonlinear elastic behavior with negligible hysteresis. The in situ XRD profiles show that the superelastic mechanism of the alloy with a higher $\mathrm{O}$ content is fundamentally different from that of the alloy with a lower $\mathrm{O}$ content. The in situ XRD profiles of the 0.30 alloy clearly show that the superelasticity is associated with the stress-induced martensitic transformation from $\beta$ to $\alpha^{\prime \prime}$ and its reverse transformation. By contrast, the in situ XRD profiles of 1.50 alloy show that no clear martensitic transformation occurs upon loading. It can
Fig. 6 Effect of oxygen addition on the shape memory properties of $\mathrm{Ti}-\mathrm{Nb}$ alloys
Ti- $x$ Nb-1O

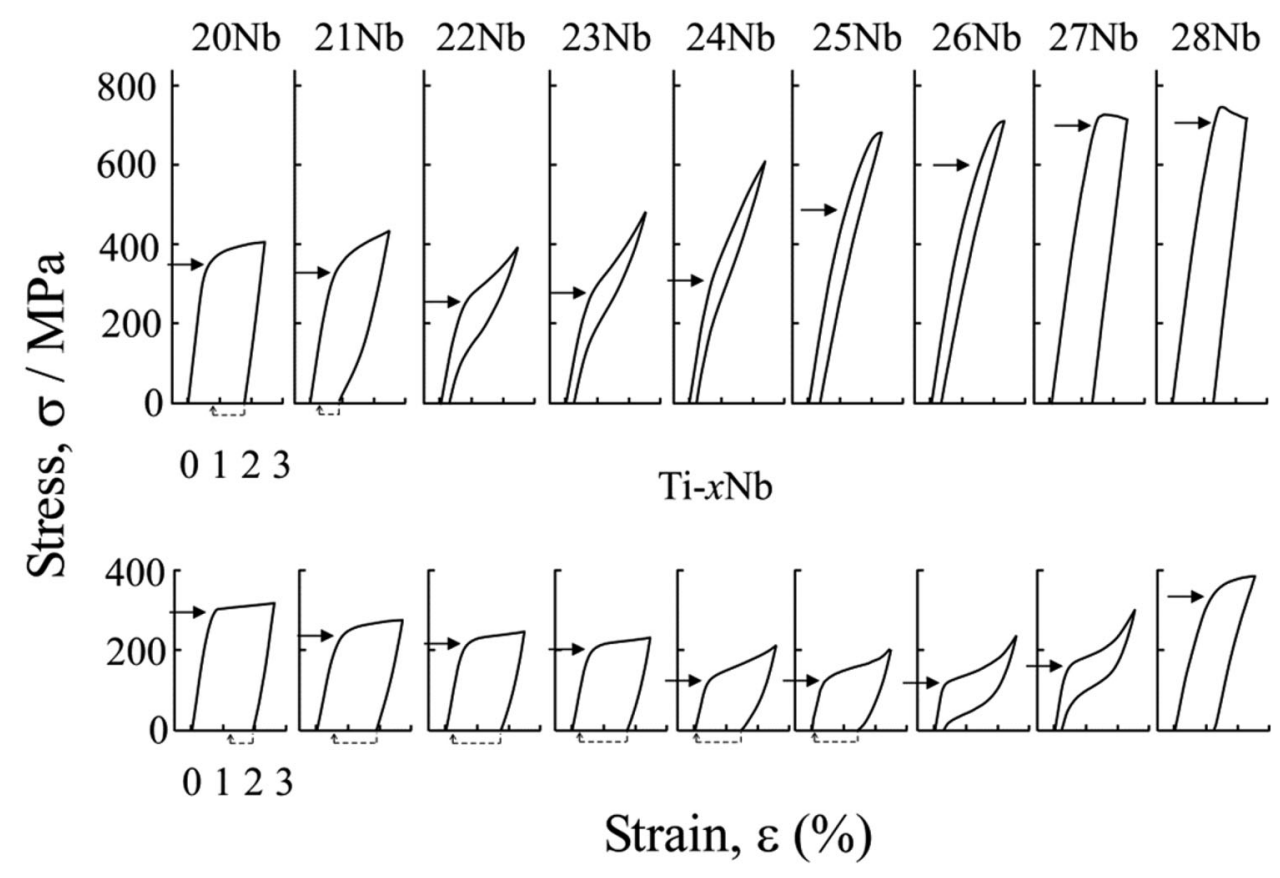


Fig. 7 a $\mathrm{O}$ content dependence of deformation behavior in $\mathrm{Ti}-$ $23 \mathrm{Nb}-2 \mathrm{Zr}-0.7 \mathrm{Ta}-x \mathrm{O}$ alloys and in situ XRD profiles during loading and unloading for the b 0.3 and c $1.5 \mathrm{O}$ alloys (a)
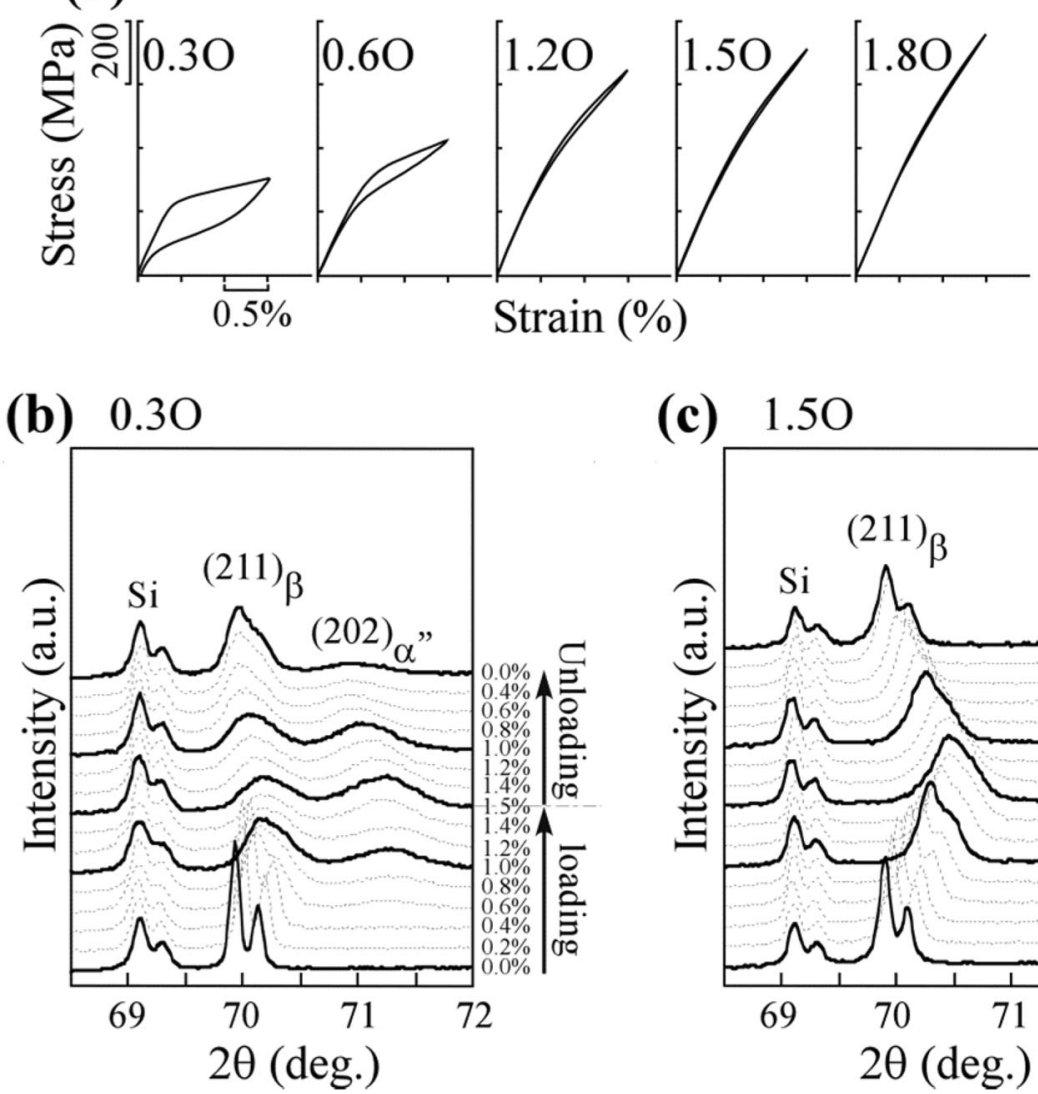

(c) 1.50

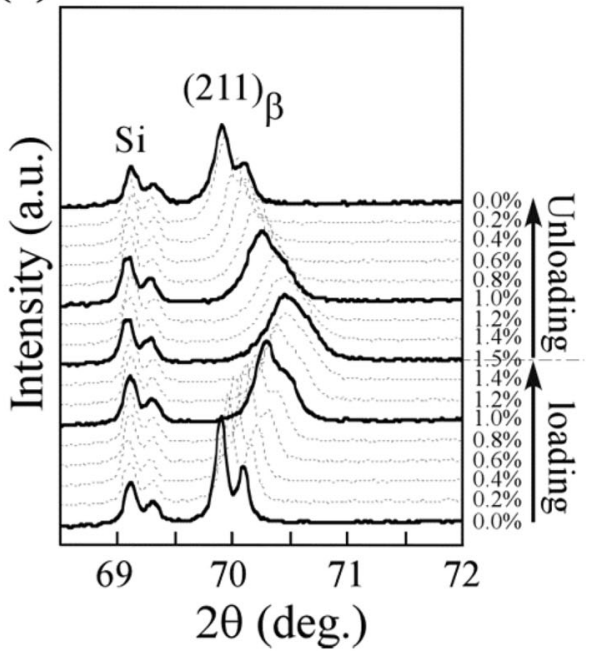

only be seen that the $211_{\beta}$ peak shifts toward a higher $2 \theta$ value and became broader with increasing applied strain, implying that the degree of lattice distortion gradually increases with increasing applied stress. The suppression of the long-range martensitic transformation by the addition of $\mathrm{O}$ has also been confirmed by DSC analysis and microstructure observation $[56,59,60]$. It has been elucidated that the suppression of the long-range martensitic transformation by the addition of $\mathrm{O}$ is due to the nanosized lattice modulation (nano-domain) structure produced by local strain fields of interstitial $O$ atoms [56, 59]. The anomalous behavior of thermal expansion, i.e., Invar-like behavior in Gum metal, has been successfully explained by a nano-domain structure which is governed by the concentration of oxygen, the stability of $\beta$ phase, and applied stress [61, 62].

The addition of $\mathrm{N}$ also suppresses the long-range martensitic transformation of $\mathrm{Ti}-\mathrm{Nb}$-based alloys. It has been reported that the addition of 1 at. $\% \mathrm{~N}$ to $\mathrm{Ti}-\mathrm{Nb}$-based alloys decreases the martensitic transformation temperature by $160-200 \mathrm{~K}[15,32]$. The addition of $\mathrm{N}$ has been found to improve the superelastic properties of $\mathrm{Ti}-\mathrm{Nb}$-based alloys. Figure 8 shows the stress-strain curves of $\mathrm{Ti}-27 \mathrm{Nb}$ and $\mathrm{Ti}-23 \mathrm{Nb}-1 \mathrm{~N}$ alloys obtained from the strain increment cyclic tensile tests at room temperature. Both alloys exhibit double-yielding behavior: the first yielding occurs at similar critical stresses which induce martensitic transformation, while the second yielding occurs at different stresses causing plastic deformation. The $\mathrm{Ti}-27 \mathrm{Nb}$ alloy exhibits superelasticity with a maximum recovery strain of $2.0 \%$ including both superelastic recovery strain and elastic strain. The small recovery strain of the $\mathrm{Ti}-27 \mathrm{Nb}$ alloy is not only due to the intrinsic small transformation strain but also because of its low critical stress for plastic deformation. The $\mathrm{Ti}-23 \mathrm{Nb}-1 \mathrm{~N}$ alloy shows a larger recovery strain

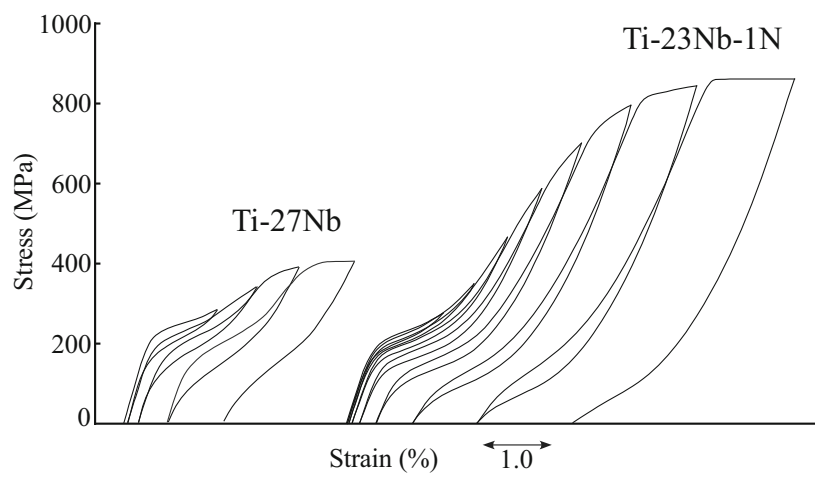

Fig. 8 Stress-strain curves of $\mathrm{Ti}-27 \mathrm{Nb}$ and $\mathrm{Ti}-23 \mathrm{Nb}-1 \mathrm{~N}$ alloys obtained from the strain increment cyclic tensile tests at room temperature 
of $3.6 \%$ mainly because of the higher critical stress for plastic deformation as clearly shown in Fig. 8. The addition of $\mathrm{N}$ gives another advantage in increasing the intrinsic transformation strain because superelasticity occurs at lower $\mathrm{Nb}$ content in the $\mathrm{N}$-added alloys. On the other hand, $\mathrm{B}$ exhibits a small effect on the shape memory properties of Ti-Nb-based alloys mainly due to the limited solubility in $\beta$ phase. Within the solubility limit, the addition of $B$ decreases the martensitic transformation temperatures remarkably with a slope of $-350 \mathrm{~K} / \mathrm{at} \% \mathrm{~B}$ [57], which is much stronger than those of $\mathrm{O}$ and $\mathrm{N}$. However, the solubility of $\mathrm{B}$ in the $\beta$ phase is only about 0.1 at. $\%$ and the excess B forms a coarse TiB intermetallic compound. Similarly, the limited solubility limit of $C$ in the $\beta$ phase also results in a weak effect on the shape memory properties of Ti-Nb-based alloys [63].

\section{Omega Phase}

The addition of $\mathrm{Zr}$ or $\mathrm{Mo}$ in replacement of $\mathrm{Nb}$ is an effective way to increase the transformation strain of $\mathrm{Ti}-$ $\mathrm{Nb}$-based alloys. However, the decrease in the $\mathrm{Nb}$ content accelerates the formation of the $\omega$ phase. It has been acknowledged that there are two types of $\omega$ phases, i.e., athermal and thermal $\omega$ phases. The athermal $\omega$ phase has
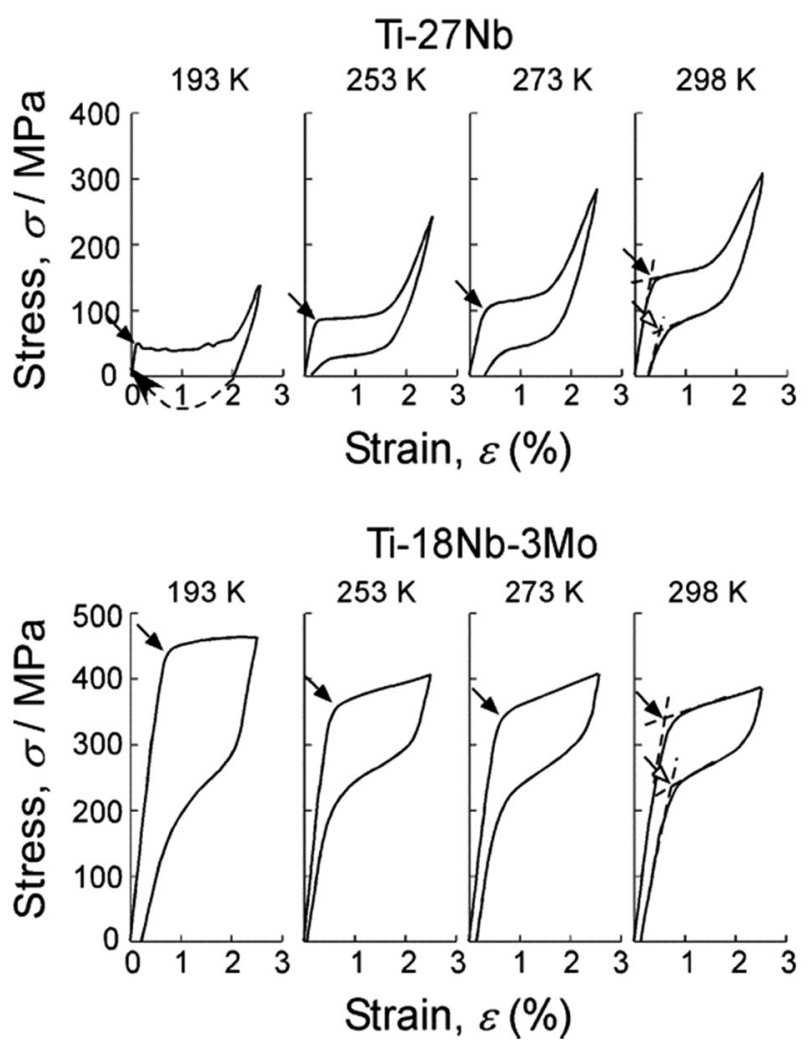

Fig. 9 Stress-strain curves of $\mathrm{Ti}-27 \mathrm{Nb}$ and $\mathrm{Ti}-18 \mathrm{Nb}-3 \mathrm{Mo}$ alloys obtained at various temperatures between 193 and $298 \mathrm{~K}$ received great attention due to its anomalous electrical properties. Recently, it has been reported that the athermal $\omega$ phase strongly affects the martensitic transformation behavior and shape memory properties of $\beta$-Ti alloys $[35,64]$. Figure 9 shows the comparison of test temperature dependence of shape memory properties of $\mathrm{Ti}-27 \mathrm{Nb}$ and $\mathrm{Ti}-18 \mathrm{Nb}-3 \mathrm{Mo}$ alloys. Both alloys exhibit superelasticity at room temperature (298 K) [64]. A solid-headed arrow indicates the critical stress for inducing martensitic transformation from $\beta$ to $\alpha^{\prime \prime}$. For the Ti-27Nb alloy, the critical stress for inducing martensitic transformation decreases with the decreasing test temperature, which is consistent with the Clausius-Clapeyron relationship of the stress-induced martensitic transformation. On the other hand, for the $\mathrm{Ti}-18 \mathrm{Nb}-3 \mathrm{Mo}$ alloy, the critical stress for inducing martensitic transformation increases with the decreasing test temperature. This opposite temperature dependence of critical stress for inducing martensitic transformation in the $\mathrm{Ti}-18 \mathrm{Nb}-3 \mathrm{Mo}$ alloy can be explained by the competition between the $\beta-\omega$ transformation and the $\beta-\alpha^{\prime \prime}$ transformation. The Ti-18Nb-3Mo alloy has a strong tendency to form athermal $\omega$ phase upon cooling. The formation of athermal $\omega$ phase hinders the martensitic transformation from $\beta$ to $\alpha^{\prime \prime}$ and raises the critical stress for inducing martensitic transformation. It is noted from Fig. 9 that the stress hysteresis increases with the decreasing test temperature in the $\mathrm{Ti}-18 \mathrm{Nb}-3 \mathrm{Mo}$ alloy. This is because the stress for reverse transformation from $\alpha^{\prime \prime}$ to $\beta$ decreases with the decreasing test temperature for both alloys, indicating that the effect of the athermal $\omega$ phase is weak during the reverse transformation from $\alpha^{\prime \prime}$ to $\beta$. This has been suggested to be due to the fact that the $\omega$ phase transforms to the $\alpha^{\prime \prime}$ phase along with the $\beta$ phase. However, a detailed mechanism of the transformation between the $\omega$ phase and the $\alpha^{\prime \prime}$ phase has not yet been clarified. The increase in the stress hysteresis leads to the deterioration of superelastic properties. Some alloying elements, particularly $\mathrm{Al}, \mathrm{Sn}$, and $\mathrm{O}$, have been reported to be effective in suppressing the formation of the athermal $\omega$ phase [38, 65, 66]. Figure 10 shows the stress-strain curves of

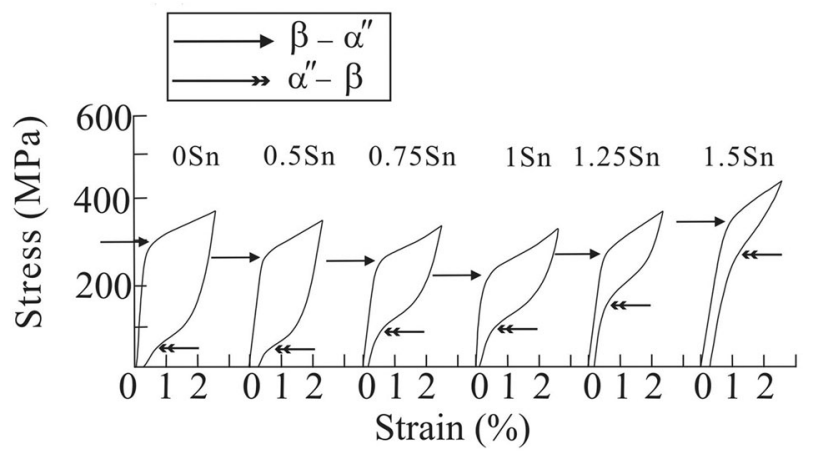

Fig. 10 Stress-strain curves of $\mathrm{Ti}-15 \mathrm{Nb}-3 \mathrm{Mo}-(0-1.5) \mathrm{Sn}$ alloys 

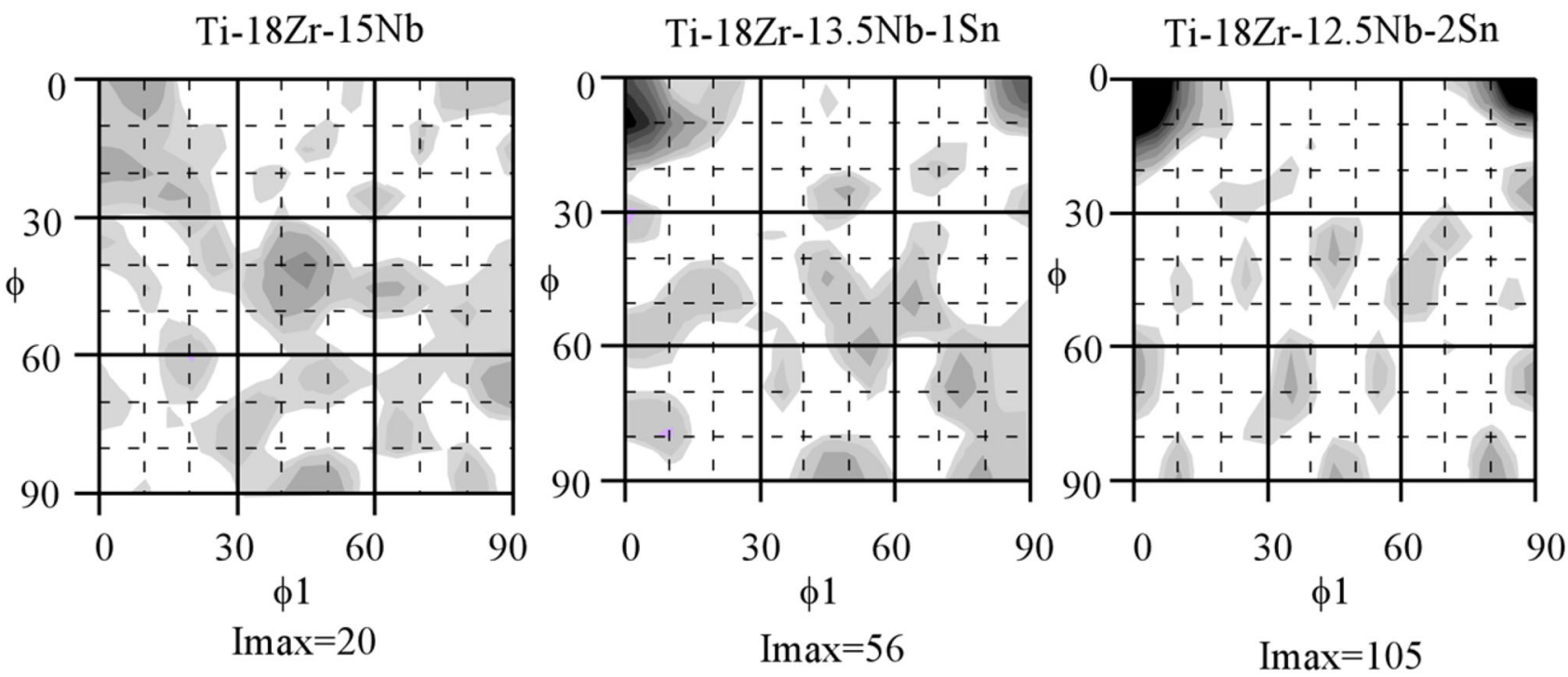

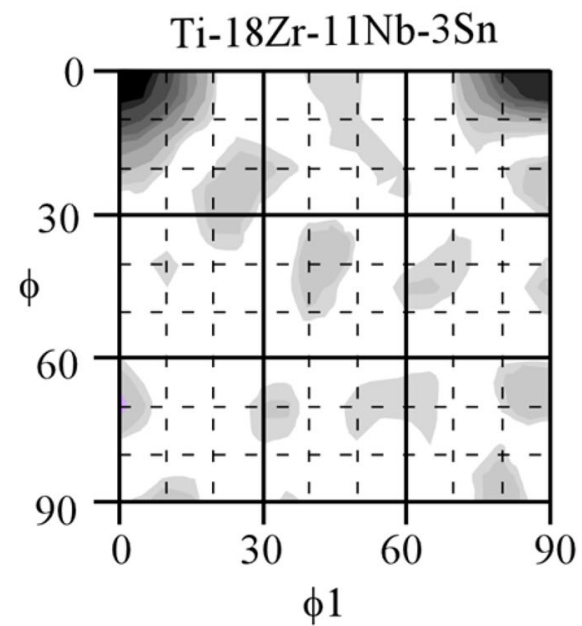

$\operatorname{Imax}=82$
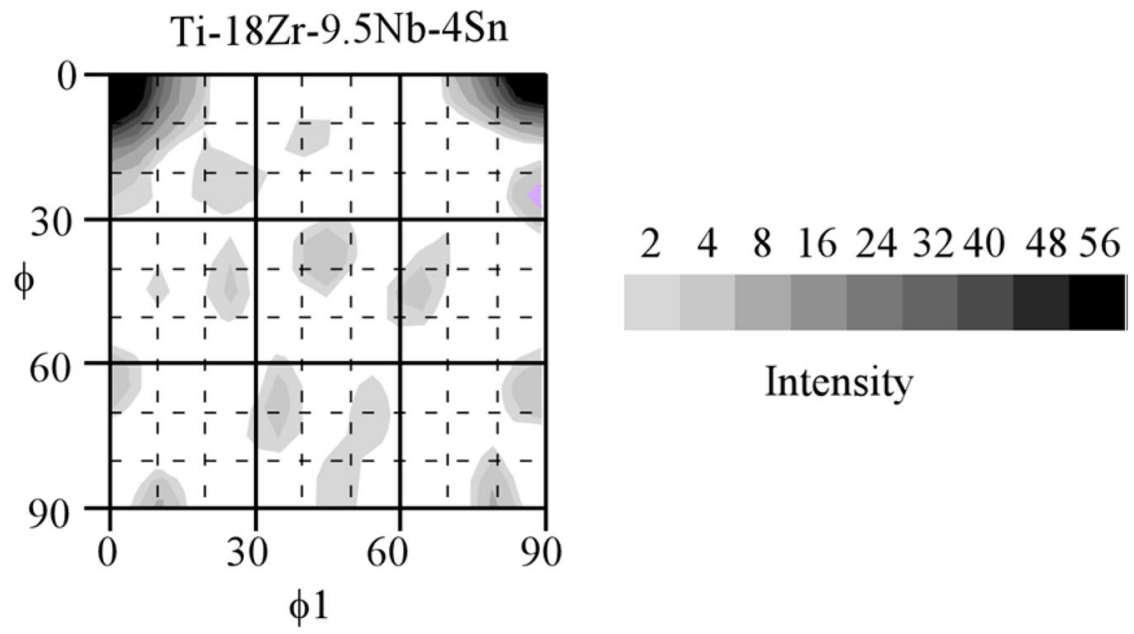

Intensity

Fig. 11 Orientation distribution function (ODF) of Ti-18Zr-15Nb, Ti-18Zr-13.5Nb-1Sn, Ti-18Zr-12.5Nb-2Sn, Ti-18Zr-11Nb-3Sn, and Ti$18 \mathrm{Zr}-9.5 \mathrm{Nb}-4 \mathrm{Sn}$ alloys solution-treated at $1173 \mathrm{~K}$ for $1.8 \mathrm{ks}$

Ti-15Nb-3Mo-(0-1.5)Sn alloys [38]. It is very evident that, with increasing Sn content, the critical stress for inducing martensitic transformation decreases and the stress hysteresis becomes narrower. The suppression of the athermal $\omega$ phase leads to the increase in superelastic recovery strain.

\section{Texture}

Texture is one of the most important microstructural factors because the transformation strain is highly anisotropic. The Ti-27Nb alloy, which exhibits superelasticity in the binary $\mathrm{Ti}-\mathrm{Nb}$ system, exhibits a strong $\{100\}\langle 011\rangle$ texture in the asrolled state and a $\{211\}\langle 011\rangle$ texture after recrystallization.
The recrystallization texture of $\{211\}\langle 011\rangle$ has been also reported to form in $\mathrm{Ti}-22 \mathrm{Nb}-6 \mathrm{Ta}$ [20] and $\mathrm{Ti}-24 \mathrm{Nb}-3 \mathrm{Al}$ [67], which have relatively large amounts of $\mathrm{Nb}$. As mentioned previously, the transformation strain due to the martensitic transformation from $\beta$ to $\alpha^{\prime \prime}$ is maximized along the direction of [011]. Therefore, both the cold rolling texture and the recrystallization texture are advantageous for superelastic properties, particularly for increasing recovery strain. However, the decrease in the $\mathrm{Nb}$ content, in order to increase the transformation strain, causes the change of the recrystallization texture. Figure 11 shows $\phi_{2}=45^{\circ}$ sections of orientation distribution function (ODF) of Ti-18Zr-15Nb, Ti-18Zr-13.5Nb-1Sn, Ti-18Zr-12.5Nb-2Sn, Ti-18Zr$11 \mathrm{Nb}-3 \mathrm{Sn}$, and $\mathrm{Ti}-18 \mathrm{Zr}-9.5 \mathrm{Nb}-4 \mathrm{Sn}$ alloys solution-treated at $1173 \mathrm{~K}$ for $1.8 \mathrm{ks}$ after cold rolling with a reduction ratio 
Fig. 12 Stress-strain curves obtained from cyclic tensile tests of $\mathrm{Ti}-18 \mathrm{Zr}-x \mathrm{Nb}-y \mathrm{Sn}$ alloys: a Ti-18Zr-15Nb, b Ti$18 \mathrm{Zr}-13.5 \mathrm{Nb}-1 \mathrm{Sn}, \mathbf{c} \mathrm{Ti}-18 \mathrm{Zr}-$ $12.5 \mathrm{Nb}-2 \mathrm{Sn}, \mathbf{d} \mathrm{Ti}-18 \mathrm{Zr}-11 \mathrm{Nb}-$ $3 \mathrm{Sn}$, and e $\mathrm{Ti}-18 \mathrm{Zr}-9.5 \mathrm{Nb}-4 \mathrm{Sn}$ and $\mathbf{f}$ the measurement scheme of superelastic properties
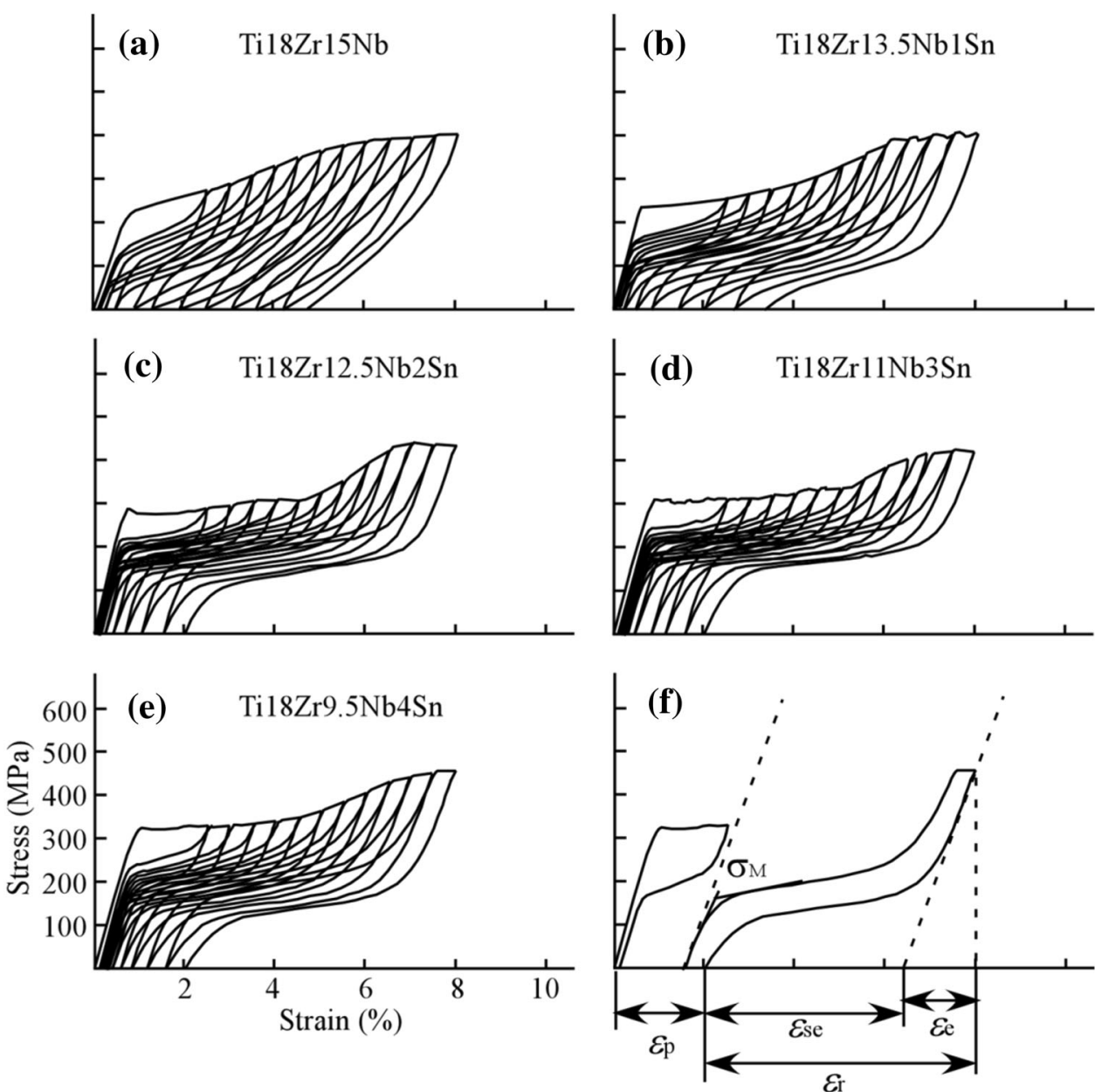

of $98.5 \%$ [42]. The $\mathrm{Ti}-18 \mathrm{Zr}-15 \mathrm{Nb}$ alloy exhibits a weak recrystallization texture with a major component close to $\{211\}\langle 120\rangle$. This is probably due to a different deformation texture, which is associated with deformation behavior; however, no clear explanation has been reported regarding the effect of alloy composition on the deformation texture. This weak texture is not preferable for a lager transformation strain. On the other hand, the Sn-added alloys exhibit a very strong recrystallization texture of $\{100\}\langle 011\rangle$, which produces the largest transformation strain along the rolling direction. The improvement of superelastic properties is confirmed by cyclic tensile tests as shown in Fig. 12 [42].

\section{Concluding Remarks}

Recent researches have provided important insight into the understanding of the effect of alloying elements on the microstructure, martensitic transformation behavior, and superelastic properties of $\mathrm{Ti}-\mathrm{Nb}$ alloys. It has been well documented that the superelastic properties of $\mathrm{Ti}-\mathrm{Nb}$ alloys can be markedly improved by the addition of alloying elements. $\mathrm{Zr}$ is the most effective alloying element in increasing the superelastic recovery strain because the addition of $\mathrm{Zr}$ in replacement of $\mathrm{Nb}$ decreases the transformation temperature but has a relatively weak impact on the transformation strain. Mo is also effective to increase the transformation strain if it is added while maintaining the same transformation temperature. On the other hand, the decrease in the amount of $\beta$ phase stabilizing elements facilitates the formation of $\omega$ phase causing detrimental effects on the superelastic properties. The addition of $\mathrm{Sn}$ is effective for suppressing the formation of $\omega$ phase. As a result, it is proposed that $\mathrm{Ti}-\mathrm{Zr}-\mathrm{Nb}-\mathrm{Sn}$ and $\mathrm{Ti}-\mathrm{Zr}-\mathrm{Mo}-\mathrm{Sn}$ alloys are promising candidates for practical biomedical superelastic alloys. For example, it has been reported to exhibit a large recovery strain of about $7 \%$ in $\mathrm{Ti}-24 \mathrm{Zr}-$ $10 \mathrm{Nb}-2 \mathrm{Sn}$ and $\mathrm{Ti}-\mathrm{Zr}-1.5 \mathrm{Mo}-3 \mathrm{Sn}$ alloys. Texture is one of the important factors to determine the superelastic properties. Not only the deformation texture but also the recrystallization texture is changed by the alloying element. However, much remains unclear about the effect of alloying element on the texture development of $\mathrm{Ti}$ alloys. Interstitial alloying elements such as oxygen and nitrogen 
have attracted particular attention because of many unique properties such as larger elastic strain, invar-like behavior, and nonlinear elastic behavior. In addition, the interstitial alloying element is very effective in increasing the critical stress for plastic deformation and improving the superelastic properties. Although there still remains a lack of quantitative research, Ti-based superelastic alloys are expected to expand the application fields of shape memory alloys.

Acknowledgements This work was partially supported by JSPS KAKENHI Grant Number 26249104 and MEXT KAKENHI Grant Number 25102704.

\section{References}

1. Miyazaki S, Kim HY, Hosoda H (2006) Development and characterization of $\mathrm{Ni}$-free Ti-base shape memory and superelastic alloys. Mater Sci Eng A 438-440:18-24

2. Miyazaki S, Kim HY (2006) TiNi-base and Ti-base shape memory alloys. Mater Sci Forum 561-565:5-21

3. Kim HY, Miyazaki S (2015) Martensitic transformation and superelastic properties of $\mathrm{Ti}-\mathrm{Nb}$ base alloys. Mater Trans 56: 625-634

4. Kim HY, Hashimoto S, Kim JI, Hosoda H, Miyazaki S (2004) Mechanical properties and shape memory behavior of $\mathrm{Ti}-\mathrm{Nb}$ alloys. Mater Trans 45:2443-2448

5. Kim HY, Ikehara Y, Kim JI, Hosoda H, Miyazaki S (2006) Martensitic transformation, shape memory effect and superelasticity of Ti-Nb binary alloys. Acta Mater 54:2419-2429

6. Takahashi E, Sakurai T, Watanabe S, Masahashi N, Hanada S (2002) Effect of heat treatment and Sn content on superelasticity in biocompatible TiNbSn alloys. Mater Trans 43:2978-2983

7. Matsumoto H, Watanabe S, Hanada S (2007) Microstructures and mechanical properties of metastable $\beta$ TiNbSn alloys cold rolled and heat treated. J Alloy Compd 439:146-155

8. Semboshi S, Shirai T, Konno TJ, Hanada S (2008) In-Situ transmission electron microscopy observation on the phase transformation of $\mathrm{Ti}-\mathrm{Nb}-\mathrm{Sn}$ shape memory alloys. Metall Mater Trans A 39:2820-2829

9. Wang BL, Zheng YF, Zhao LC (2008) Effects of Sn content on the microstructure, phase constitution and shape memory effect of Ti-Nb-Sn alloys. Mater Sci Eng A 486:146-151

10. Fukui $\mathrm{Y}$, Inamura $\mathrm{T}$, Hosoda $\mathrm{H}$, Wakashima $\mathrm{K}$, Miyazaki $\mathrm{S}$ (2004) Mechanical properties of a $\mathrm{Ti}-\mathrm{Nb}-\mathrm{Al}$ shape memory alloy. Mater Trans 45:1077-1082

11. Masumoto K, Horiuchi $\mathrm{Y}$, Inamura $\mathrm{T}$, Hosoda $\mathrm{H}$, Wakashima $\mathrm{K}$, Kim HY, Miyazaki S (2006) Effect of Si addition on superelastic properties of $\mathrm{Ti}-\mathrm{Nb}-\mathrm{Al}$ biomedical shape memory alloys. Mater Sci Eng A 438-440:835-838

12. Hosoda H, Kinoshita Y, Fukui Y, Inamura T, Wakashima K, Kim HY, Miyazaki S (2006) Effects of short time heat treatment on superelastic properties of a $\mathrm{Ti}-\mathrm{Nb}-\mathrm{Al}$ biomedical shape memory alloy. Mater Sci Eng A 438-440:870-874

13. Kim JI, Kim HY, Hosoda H, Miyazaki S (2005) Shape memory behavior of $\mathrm{Ti}-22 \mathrm{Nb}-(0.5-2.0) \mathrm{O}$ (at.\%) biomedical alloys. Mater Trans 46:852-857

14. Ramarolahy A, Castany P, Prima F, Laheurte P, Peron I, Gloriant $\mathrm{T}$ (2012) Microstructure and mechanical behavior of superelastic $\mathrm{Ti}-24 \mathrm{Nb}-0.5 \mathrm{O}$ and $\mathrm{Ti}-24 \mathrm{Nb}-0.5 \mathrm{~N}$ biomedical alloys. J Mech Behav Biomed Mater 9:83-90
15. Tahara M, Kim HY, Hosoda H, Miyazaki S (2009) Shape memory effect and cyclic deformation behavior of $\mathrm{Ti}-\mathrm{Nb}-\mathrm{N}$ alloys. Funct Mater Lett 2:79-82

16. Al-Zain Y, Kim HY, Hosoda H, Nam TH, Miyazaki S (2010) Shape memory properties of $\mathrm{Ti}-\mathrm{Nb}-\mathrm{Mo}$ biomedical alloys. Acta Mater 58:4212-4223

17. Kim HY, Oshika N, Kim JI, Inamura T, Hosoda H, Miyazaki S (2007) Martensitic transformation and superelasticity of $\mathrm{Ti}-\mathrm{Nb}-$ Pt alloys. Mater Trans 48:400-406

18. Ping DH, Mitarai Y, Yin FX (2005) Microstructure and shape memory behavior of a Ti-30Nb-3Pd. Scr Mater 52:1287-1291

19. Kim HY, Hashimoto S, Kim JI, Inamura T, Hosoda H, Miyazaki $S$ (2006) Effect of Ta addition on shape memory behavior of Ti$22 \mathrm{Nb}$ alloy. Mater Sci Eng A 417:120-128

20. Kim HY, Sasaki T, Okutsu K, Kim JI, Inamura T, Hosoda H, Miyazaki S (2006) Texture and shape memory behavior of Ti22Nb-6Ta alloy. Acta Mater 54:423-433

21. Bertrand E, Gloriant T, Gordin DM, Vasilescu E, Drob P, Vasilescu C, Drob SI (2010) Synthesis and characterization of a new superelastic Ti-25Ta-25Nb biomedical alloy. J Mech Behav Biomed Mater 3:559-564

22. Brailovski V, Prokoshkin S, Gauthier M, Inaekyan K, Dubinskiy S, Petrzhik M, Filonov M (2011) Bulk and porous metastable beta $\mathrm{Ti}-\mathrm{Nb}-\mathrm{Zr}(\mathrm{Ta})$ alloys for biomedical applications. Mater Sci Eng C 31:643-657

23. Bertrand E, Castany P, Gloriant T (2013) Investigation of the martensitic transformation and the damping behavior of a superelastic $\mathrm{Ti}-\mathrm{Ta}-\mathrm{Nb}$ alloy. Acta Mater 61:511-518

24. Kim JI, Kim HY, Inamura T, Hosoda H, Miyazaki S (2006) Effect of annealing temperature on microstructure and shape memory characteristics of $\mathrm{Ti}-22 \mathrm{Nb}-6 \mathrm{Zr}$ (at.\%) biomedical alloy. Mater Trans 47:505-512

25. Li Q, Niinomi M, Nakai M, Cui ZD, Zhu SL, Yang XJ (2012) Effect of $\mathrm{Zr}$ on super-elasticity and mechanical properties of Ti24 at. $\% \mathrm{Nb}-(0,2,4)$ at. $\% \mathrm{Zr}$ alloy subjected to aging treatment. Mater Sci Eng A 536:197-206

26. Kim JI, Kim HY, Inamura T, Hosoda H, Miyazaki S (2005) Shape memory characteristics of $\mathrm{Ti}-22 \mathrm{Nb}-(2-8) \mathrm{Zr}($ at. \%) biomedical alloys. Mater Sci Eng A 403:334-339

27. Tahara M, Kim HY, Inamura T, Hosoda H, Miyazaki S (2009) Effect of nitrogen addition on superelasticity of $\mathrm{Ti}-\mathrm{Zr}-\mathrm{Nb}$ alloys. Mater Trans 50:2726-2730

28. Sun F, Nowak S, Gloriant T, Laheurte P, Eberhardt A, Prima F (2010) Influence of a short thermal treatment on the superelastic properties of a Titanium-based alloy. Scr Mater 63:1053-1056

29. Cui Y, Li Y, Luo K, Xu HB (2010) Microstructure and shape memory effect of $\mathrm{Ti}-20 \mathrm{Zr}-10 \mathrm{Nb}$ alloy. Mater Sci Eng A 527:652-656

30. Sun F, Hao YL, Nowak S, Gloriant T, Laheurte P, Prima F (2011) A thermal-mechanical treatment to improve the superelastic performances of biomedical $\mathrm{Ti}-26 \mathrm{Nb}$ and $\mathrm{Ti}-20 \mathrm{Nb}-6 \mathrm{Zr}(\mathrm{at} . \%)$ alloys. J Mech Behav Biomed Mater 4:1864-1872

31. Zhang JY, Sun F, Hao YL, Gozdecki N, Lebrun E, Vermaut P, Portier R, Gloriant T, Laheurte P, Prima F (2013) Influence of equiatomic $\mathrm{Zr} / \mathrm{Nb}$ substitution on superelastic behavior of $\mathrm{Ti}-$ $\mathrm{Nb}-\mathrm{Zr}$ alloy. Mater Sci Eng A 563:78-85

32. Tahara M, Kim HY, Hosoda H, Nam TY, Miyazaki S (2010) Effect of nitrogen addition and annealing temperature on superelastic properties of $\mathrm{Ti}-\mathrm{Nb}-\mathrm{Zr}-\mathrm{Ta}$ alloys. Mater Sci Eng A 527:6844-6852

33. Sakaguch N, Niinomi M, Akahori T (2004) Tensile deformation behavior of $\mathrm{Ti}-\mathrm{Nb}-\mathrm{Ta}-\mathrm{Zr}$ biomedical alloys. Mater Trans 45:1113-1119

34. Wang LQ, Lu WJ, Qin JN, Zhang F, Zhang D (2008) Texture and superelastic behavior of cold-rolled TiNbTaZr alloy. Mater Sci Eng A 491:372-377 
35. Al-Zain Y, Sato Y, Kim HY, Hosoda H, Nam TH, Miyazaki S (2012) Room temperature aging behavior of Ti-Nb-Mo-based superelastic alloys. Acta Mater 60:2437-2447

36. Zhang DC, Yang S, Wei M, Mao YF, Tan CG, Lin JG (2012) Effect of Sn addition on the microstructure and superelasticity in Ti-Nb-Mo-Sn alloys. J Mech Behav Biomed Mater 13:156-165

37. Zhang DC, Mao YF, Yan M, Li JJ, Su EL, Li YL, Tan SW, Lin JG (2013) Superelastic behavior of a $\beta$-type titanium alloy. J Mech Behav Biomed Mater 20:29-35

38. Ijaz MF, Kim HY, Hosoda H, Miyazaki S (2014) Effect of Sn addition on stress hysteresis and superelastic properties of a $\mathrm{Ti}-$ 15Nb-3Mo alloy. Scr Mater 72-73:29-32

39. Hao YL, Li SJ, Sun SY, Yang R (2006) Effect of Zr and Sn on Young's modulus and superelasticity of Ti-Nb-based alloys. Mater Sci Eng A 441:112-118

40. Li SJ, Cui TC, Hao YL, Yang R (2008) Fatigue properties of a metastable $\beta$-type titanium alloy with reversible phase transformation. Acta Biomater 4:305-317

41. Obbard EG, Hao YL, Talling RJ, Li SJ, Zhang YW, Dye D, Yang $R$ (2011) The effect of oxygen on $\alpha^{\prime \prime}$ martensite and superelasticity in Ti-24Nb-4Zr-8Sn. Acta Mater 59:112-125

42. Fu J, Yamamoto A, Kim HY, Hosoda H, Miyazaki S (2015) Novel Ti-base superelastic alloys with large recovery strain and excellent biocompatibility. Acta Biomater 17:56-67

43. Pavón LL, Kim HY, Hosoda H, Miyazaki S (2015) Effect of Nb content and heat treatment temperature on superelastic properties of Ti-24Zr-(8-12)Nb-2Sn alloys. Scr Mater 95:46-49

44. Tada H, Yamamoto T, Wang XM, Kato H (2012) Effect of Al addition on superelastic properties of aged $\mathrm{Ti}-\mathrm{Nb}-\mathrm{Zr}-\mathrm{Al}$ quaternary alloys. Mater Trans 53:1981-1985

45. Kent D, Wang G, Yu Z, Dargusch MS (2010) Pseudoelastic behaviour of a $\beta$ Ti-25Nb-3Zr-3Mo-2Sn alloy. Mater Sci Eng A 527:2246-2252

46. Banumathy S, Mandal RK, Singh AK (2009) Structure of orthorhombic martensitic phase in binary $\mathrm{Ti}-\mathrm{Nb}$ alloys. J App Phys 106:093518

47. Bönisch M, Calin M, Giebeler L, Helth A, Gebert A, Skrotzki W, Eckert J (2014) Composition-dependent magnitude of atomic shuffles in Ti-Nb martensites. J App Cryst 47:1374-1379

48. Dubinskiy S, Prokoshkin S, Brailovski V, Inaekyan K, Korotitskiy A (2014) In situ X-ray diffraction strain-controlled study of $\mathrm{Ti}-\mathrm{Nb}-\mathrm{Zr}$ and $\mathrm{Ti}-\mathrm{Nb}-\mathrm{Ta}$ shape memory alloys: crystal lattice and transformation features. Mater Character 88:127-142

49. Kim HY, Fu J, Tobe H, Kim JI, Miyazaki S (2015) Crystal structure, transformation strain, and superelastic property of Ti$\mathrm{Nb}-\mathrm{Zr}$ and $\mathrm{Ti}-\mathrm{Nb}-\mathrm{Ta}$ alloys. Shape Mem Superelasticity 1:107-116

50. Ojha A, Sehitoglu H (2016) Slip resistance of Ti-based hightemperature shape memory alloys. Shape Mem Superelasticity 2:50-61

51. Ojha A, Sehitoglu H (2016) Critical stresses for twinning, slip, and transformation in Ti-based shape memory alloys. Shape Mem Superelasticity 2:180-195

52. Inamura T, Kim JI, Kim HY, Hosoda H, Wakashima K, Miyazaki S (2007) Composition dependent crystallography of
$\& \alpha$-martensite in Ti-Nb-based $\beta$-titanium alloy. Philos Mag $87: 3325-3350$

53. Horiuchi Y, Nakayama K, Inamura T, Kim HY, Wakashima K, Miyazaki S, Hosoda $\mathrm{H}$ (2007) Effect of $\mathrm{Cu}$ addition on shape memory behavior of $\mathrm{Ti}-18 \mathrm{~mol} \% \mathrm{Nb}$ alloys. Mater Trans 48 : 414-421

54. Horiuchi Y, Inamura T, Kim HY, Wakashima K, Miyazaki S, Hosoda $\mathrm{H}$ (2006) X-ray diffraction analysis of Ti-18 mol\% $\mathrm{Nb}$ based shape memory alloys containing $3 \mathrm{~d}$ transition metal elements. Mater Trans 48:1209-1213

55. Inamura T, Fukui $\mathrm{Y}$, Hosoda $\mathrm{H}$, Wakashima K, Miyazaki $\mathrm{S}$ (2005) Mechanical properties of Ti-Nb biomedical shape memory alloys containing Ge or Ga. Mater Sci Eng C 25:426-432

56. Tahara M, Kim HY, Inamura T, Hosoda H, Miyazaki S (2011) Lattice modulation and superelasticity in oxygen-added $\beta$-Ti alloys. Acta Mater 59:2608-2618

57. Yazan AZ, Kim HY, Miyazaki S (2015) Effect of B addition on the microstructure and superelastic properties of a $\mathrm{Ti}-26 \mathrm{Nb}$ alloy. Mater Sci Eng 644:85-89

58. Wei LS, Kim HY, Koyano T, Miyazaki S (2016) Effects of oxygen concentration and temperature on deformation behavior of $\mathrm{Ti}-\mathrm{Nb}-\mathrm{Zr}-\mathrm{Ta}-\mathrm{O}$ alloys. Scr Mater 123:55-58

59. Nii Y, Arima T, Kim HY, Miyazaki S (2010) Effect of randomness on ferroelastic transitions: disorder-induced hysteresis loop rounding in $\mathrm{Ti}-\mathrm{Nb}-\mathrm{O}$ martensitic alloy. Phys Rev B $82: 14104$

60. Tahara M, Kanaya T, Kim HY, Inamura T, Hosoda H, Miyazaki S (2014) Heating-induced martensitic transformation and timedependent shape memory behavior of $\mathrm{Ti}-\mathrm{Nb}-\mathrm{O}$ alloy. Acta Mater 80:317-326

61. Kim HY, Wei LS, Kobayashi S, Tahara M, Miyazaki S (2013) Nanodomain structure and its effect on abnormal thermal expansion behavior of a $\mathrm{Ti}-23 \mathrm{Nb}-2 \mathrm{Zr}-0.7 \mathrm{Ta}-1.2 \mathrm{O}$ alloy. Acta Mater 67:4874-4886

62. Wei LS, Kim HY, Miyazaki S (2015) Effects of oxygen concentration and phase stability on nano-domain structure and thermal expansion behavior of $\mathrm{Ti}-\mathrm{Nb}-\mathrm{Zr}-\mathrm{Ta}-\mathrm{O}$ alloys. Acta Mater 100:313-322

63. Hosoda H, Horiuchi Y, Inamura T, Wakashima K, Kim HY, Miyazaki S (2010) Effect of carbon addition of shape memory properties of TiNb alloys. Mater Sci Forum 638-642:2046-2051

64. Al-Zain Y, Kim HY, Koyano T, Hosoda H, Nam TH, Miyazaki S (2011) Anomalous temperature dependence of the superelastic behavior of Ti-Nb-Mo alloys. Acta Mater 59:1464-1773

65. Yamada K, Ogawa A, Ouchi C, Eylon D (1996) Effect of Al on $\omega$ phase transformation behavior in $\mathrm{Ti}-8 \mathrm{~V}-5 \mathrm{Fe}-(1-3) \mathrm{Al}$ alloy. Mater Trans JIM 37:855-859

66. Tane M, Nakano T, Kuramoto S, Hara M, Niinomi M, Takesue N, Yano T, Nakajima H (2011) Low Young's modulus in Ti-NbTa-Zr-O alloys: cold working and oxygen effects. Acta Mater 59:6975-6988

67. Inamura $\mathrm{T}$, Horiuchi $\mathrm{Y}$, Hosoda $\mathrm{H}$, Wakashima $\mathrm{K}$, Miyazaki S (2004) Relationship between texture and macroscopic transformation strain in severely cold-rolled $\mathrm{Ti}-\mathrm{Nb}-\mathrm{Al}$ superelastic alloy. Mater Trans 45:1083-1089 